\title{
Analysis of Farmers' Perception on the Impact of Land Degradation Hazard on Agricultural Land Productivity in Jeldu District in West Shewa Zone, Oromia, Ethiopia
}

\author{
Tesfaye Samuel Saguye ${ }^{1}$ \\ ${ }^{1}$ Department of Disaster Risk Management and Sustainable Development, Institute of Cooperatives and \\ Development Studies, Ambo University, Ambo, Ethiopia \\ Correspondence: Tesfaye Samuel Saguye, Department of Disaster Risk Management and Sustainable \\ Development, Institute of Cooperatives and Development Studies, Ambo University, Ambo, Ethiopia. E-mail: \\ gezegofa@gmail.com
}

\author{
Received: April 12, 2018 Accepted: April 25, 2018 Online Published: November 26, 2018 \\ doi:10.5539/eer.v8n2p20 URL: https://doi.org/10.5539/eer.v8n2p20
}

\begin{abstract}
Land degradation is increasing in severity and extent in many parts of the world. Success in arresting land degradation entails an improved understanding of its causes, process, indicators and impacts. Various scientific methodologies have been employed to assess land degradation globally. However, the use of local community knowledge in elucidating the causes, process, indicators and effects of land degradation has seen little application by scientists and policy makers. Land degradation may be a physical process, but its underlying causes are firmly rooted in the socio-economic, political and cultural environment in which land users operate. Analyzing the root causes and effects of land degradation from local community knowledge, perception and adapting strategies perspective will provide information that is essential for designing and promoting sustainable land management practices. The main objective of this study was to analyze the perceptions of farmers' on the impact of land degradation hazard on agricultural land productivity decline associated with soil erosion and fertility loss. The study used a multistage sampling procedure to select sample respondent households. The sample size of the study was 120 household heads and 226 farm plots managed by these farmers. The primary data of the study were collected by using semi-structured Interview, focus group discussions and field observation. Both descriptive statistics and econometric techniques were used for data analysis. Descriptive results show that 57 percent of the respondents were perceived the severity and its consequence on agricultural land productivity. The following indicators of soil erosion and fertility loss were generally perceived and observed by farmers' in the study area: gullies formations, soil accumulation around clumps of vegetation, soil deposits on gentle slopes, exposed roots, muddy water, sedimentation in streams and rivers, change in vegetation species, increased runoff, and reduced rooting depth. The direct human activities which were perceived to be causing land degradation in the study area include: deforestation and clearing of vegetation, overgrazing, steep slope cultivation and continuous cropping. The farmers' possibility of perceiving the impact of land degradation hazard on agricultural land productivity was primarily determined by institutional, psychological, demographic and by bio-physical factors. Farmers who perceive their land as deteriorating and producing less than desired, tend to adopt improved land management practices. On the other hand, farmers who perceive their land to be fertile tend to have low adoption of conservation practices. In order to overcome this land degradation and its consequent effects, the study recommended a need for the government to enforce effective policies to control and prevent land degradation and these policies should be community inclusive /participatory founded up on indigenous and age-honored knowledge and tradition of farmers' natural resource management as well as introduced scientific practices.
\end{abstract}

Keywords: farmers' perception, land degradation, impact of land degradation, agricultural land productivity

\section{Introduction}

\subsection{Background of the Study}

Ethiopia is one of the Sub-Saharan Africa countries most severely affected by land degradation problem. Among the SSA countries, Ethiopia has a high level of soil erosion (FAO, 2011; World Bank, 2012; Tesfaye and Mekuriaw, 2014; Aklilu, 2006). Agriculture is the economic mainstay of the overwhelming majority of Ethiopian people and 
will continue to remain so in the near future. However, the on-going land degradation has threatened undermining the sustenance of their livelihood. Land degradation is a major cause of the country's low and declining agricultural productivity, persistent food insecurity, and abject rural poverty (FAO, 2006; Million Taddesse and Belay Kassa., 2007). The minimum estimated annual costs of land degradation in Ethiopia range from 2 to 3 percent of agricultural GDP (FAO, 2010). This is a significant loss for countries where agriculture accounts for nearly 45 percent of GDP, 90 percent of export revenue, and is a source of livelihood for more than 82 percent of the country's 100 million people (Bewket and Sterk, 2003, FAO, 2010,). In Ethiopia, land degradation, low and declining agricultural productivity, and poverty are severe and interrelated problems that appear to feed off each other (Tesfaye et al., 2014; Haregeweyn et al., 2015; Bewket and Teferi,2009; Seid 2009). If urgent measures are not taken to arrest Ethiopia's serious land degradation, the country is headed for a "catastrophic situation" (Pender. and Gebremedhin, 2006). Programs addressing land conservation are not succeeding where they are most needed (Tesfaye et al., 2014; Haregeweyn et al., 2015). Understanding, preventing and mitigating Land Degradation (LD) at the local scale seem to require more than technical knowledge and perception by external agents such as agricultural advisors and government officials

Land degradation is a dangerous hazard and slow process therefore farmers need to perceive its severity and the associated yield loss before they can consider implementing soil and water conservation (SWC) practices (Tesfa, and Mekuriaw, 2014). Land and water degradation and its effect on agricultural activities may be unintentional and unperceived; it may result from carelessness or from the unavoidable struggle of vulnerable populations for the necessities of survival (Teshome et al., 2016.). Understanding the local people's perceptions on environmental issues is thus a prerequisite in making successful and sustainable resource management strategies (Assefa ,2009; Alemayehu et al., 2013; Achamyeleh, 2015; Pender, and Berhanu, 2004; Wagayehu and Drake, 2003; Tesfaye et al., 2014; Haregeweyn et al., 2015; Bewket and Teferi,2009). Any effort towards this direction should begin from a research that aims at exploring location specific factors influencing the adoption of land management practices.

\subsection{Statement of the Problem and Rationale of the Study}

Land degradation is an insidious, gradual process, and farmers may not easily perceive its severity. The smallholder farmers' decision-making procedures are strongly based on their perceptions of the forces that drive degradation (Tesfaye et al., 2014; Haregeweyn et al., 2015; Bewket and Teferi, 2009) and its consequences on their lives and livelihoods. Perception will partly control awareness, goals and practical actions. Local perception refers to the causes and status of land degradation as farmers detect and express it as occurring on their lands. Both perception and knowledge guides decision making and consequently, farmers' action on land conservation and adoption of sustainable land management practices (Bewket and Sterk 2003; Amsalu and de Graaff, 2007). Interpretations of environmental change are culturally constructed and need to be thoroughly examined for a sound understanding of farmer behavior. In addition to limitations presented by availability of technology and the capacity for learning, other elements including perceptions and knowledge considerations within society fundamentally limit agricultural land management (Bekele et al. 2009; Woodfine, 2009). For farmers to decide whether or not to adopt a particular measure to cushion themselves against the potential livelihood losses, they must first perceive that land degradation has actually occurring and its severe effects on agricultural land productivity (Wagayehu and Drake, 2003 Tegene, 1992; Bewket and Sterk, 2002). Before a problem can be addressed, it must be perceived. Addressing soil erosion with the adoption of conservation practices is no exception. Unfortunately, the literature on determinants of the adoption of conservation technologies has given little attention to perception variables (Tesfa, and Mekuriaw, 2014). Agricultural technology adoption studies in Ethiopia started in the 1970's, but few of them considered the role of farmer perceptions in the adoption of improved varieties (Pender and Berhanu, 2006; Bekele and Drake, 2003; Bewket and Sterk, 2002; Haregeweyn et al., 2015. A better understanding of farmer perceptions regarding severe effect of land degradation and benefits of adoption sustainable implementation of SLM measures and their determinants will be important to influence policy for future successful adaptation of the agricultural sector (Tegene, 1992; Tesfaye et al., 2014; Assefa and Hans-Rudolf, 2016 Gebremedhin, 1998). Therefore, to enhance policy towards tackling the challenges that land degradation poses to farmers, it is important to have full understanding of farmers' perception on land degradation and its severe effects on their agricultural productivity (Tegene, 1992; Snyder et al., 2014; Tesfaye et al., 2014).

Perception of soil erosion as a hazard to agricultural production and sustainable environment is the most important determinant of effort at adoption of conservation measures. Theoretically, those farmers who perceive soil erosion as a problem having negative impacts on productivity and who expect positive returns from conservation are likely to decide in favor of adopting available conservation technologies (Tesfa, and Mekuriaw, 2014). On the other hand, when farmers do not acknowledge soil erosion as a problem, they will not expect benefits from controlling erosion and it is highly likely that they will decide against adopting any conservation technologies. Perceptions are 
important in the introduction of sustainable farming techniques at the farm level (Haregeweyn et al., 2015). A review of the relevant literature points to the fact that a number of empirical studies have been undertaken on technology adoption under Ethiopian context. However, in environmental conservation and management studies farmers' perceptions have often been overlooked. As a matter of fact, the farmers' perception is highly a certain socio-culture context specific in its very nature. Therefore, this study was conducted in view of bridging this gap. So, the specific objectives of the study are: 1) to analyze farmers' perception on the causes, indicators and impacts of land degradation on agricultural land productivity; 2) to analyze the determinants of farmers' perception on the impact of land degradation on agricultural land productivity reduction in Jeldu district in West Shewa zone of Oromia regional state, Ethiopia.

\section{Methodology of the Study}

\subsection{Description of the Study Area}

The study was conducted in Jeldu Woreda (District), West Shewa Zone, Central Ethiopia (9०02' $47^{\prime \prime}$ to $9^{\circ} 15^{\prime} 00^{\prime \prime}$ $\mathrm{N}$ and $38^{\circ} 05^{\prime} 00^{\prime \prime}$ to $38^{\circ} 12^{\prime} 16^{\prime \prime} \mathrm{E}$ which is delineated by Meta Robi, Dendi and Ejere woredas in East, Gindeberet Woreda in West, Abuna Gindeberet Woreda in North and Eliphata Woreda in South. It has an elevation range of 2500 - 3200 meter above sea level (m asl) Undulating slopes divided by V-shaped valleys of seasonal and/or relatively permanent streams characterize the topography of the study area. Steep slopes are found along the valley sides, where slopes greater than $30 \%$ are very common. Rainfall pattern is bimodal with the main rainy season from June to September and the short rainy season from February to March. The mean annual rainfall of the area ranges from 1800 to $2200 \mathrm{~mm}$. The maximum and minimum temperature of the area ranges from 17 to $22^{\circ} \mathrm{C}$. The farming system of the area is mainly rain-fed. The soil type is characterized as clay and clay-loam type, but the riverbed has a loam and sandy-loam type of soil. A eucalyptus globule is the main tree planted in the area. Jeldu's 202,655 people are scattered across a highly variable landscape of highlands (45\%), midlands (30\%) and lowlands $(25 \%)$ covering an area of 139,389 hectares (ha). The majorities of residents lives on ridge tops and cultivate steep valley slopes of up to 80 degrees of which oxen are replaced by hoes for tilling.

\subsection{Data Collection Techniques and Tools}

Data for the study were collected from both primary and secondary sources. Primary data were collected by using the following data collection techniques and tools:

1. Semi- structured Questionnaires: The household survey was conducted using semi structured questionnaires and covered detailed information at the household, plot and village levels. The data collected included information on demographic and socio-economic characteristics, institutional services, biophysical characteristics, plot level characteristics, various land management practices used by farmers (collectively or singly), resources farmers use in the practices and farmers' perceptions and attitudes on consequences and impacts of land degradation on agricultural productivity and yield. Ten enumerators, who had experience in data collection, know the area and the communities' languages were recruited and trained for two days by the researcher. The questionnaire was pretested by administering it to selected ten respondents. On the basis of the results obtained from the pretest, necessary modifications were made on the questionnaire.

2. Focus Group Discussion (FGDs): In this study, six focus group discussions consists eight to twelve participant farmers who were selected randomly conducted in the study area. The FGDs were conducted in order to get some in-detail information on land degradation nature, causes and consequences, commonly practiced land management practices, community perceptions on land degradation and its effects on agricultural activities and agricultural performance in general and constraints of adoption of sustainable land management (SLM) practices. The major issue which was explored during the group discussion includes: the extent of the farmers' participation in the SLM practices in reference to their awareness and perception of erosion hazards, and the effectiveness of the technologies under implementation. Here the researcher was limited to facilitating the discussion using a checklist of topics to guide the sessions in an orderly way. These informal techniques helped to acquire useful and detailed information, which would have been difficult to collect through the questionnaire interview.

4. Field Observation: Field visits involved observations of various land degradation features, such as soil erosion and sedimentation, surface runoff, sandiness of soils, crop vigor, presence of indicator-plant species; and agricultural practices, including among others, types of crops grown, cropping patterns and on-farm soil conservation measures. Field observation was conducted throughout the whole process of the research in order to ensure the validity of information obtained from the farmers through interview schedule. This helped to capture some points that were not clearly obtained from the interview.

\subsection{Sampling Design of the Study}


This study employed a multi-stage sampling procedure. First Jeldu district was purposively selected because it is one of the highly degraded highland areas in the country in terms of soil erosion and fertility loss. The district is a highland area with steep slopes, intensely cropped hillsides and high population densities. Second, Representative Kebeles were purposively selected based on topographical class. The study area was classified in to four topographical zones: steep, moderately steep, moderate/gentle slope and flat. The number of kebeles (Seriti, Kolu Galan and Chillanko) selected were proportional to the land area covered by each class, and the number of households selected in each village was proportional to the number of households in each village. Thirdly, the sample respondent households were selected using systematic random sampling techniques. The survey covered 120 farm households managing 226 plots during the 2015/2016 cropping season. With regard to the sampling technique, proportional simple random sampling technique was used to select sample respondents from each kebeles.

\subsection{Methods of Data analysis}

The study employed a combination of both descriptive and inferential statistics to analyze data collected from the sample respondents. To run statistical analysis, data were coded and entered in to SPSS version 20. The information generated through focus group discussions was used to substantiate and augment findings from the quantitative analysis of the structured questionnaires.

\subsubsection{Specification of Empirical Models}

The determinants of farmer perceptions of land degradation can be analyzed using qualitative response statistical models. The simplest of these models has a binary dependent variable, so the outcome of interest can take on the values 0 or 1: 1 if erosion is perceived and 0 if it is not. The binary response models focus on the factors that determine the probability of perception. It is assumed that there exists a perception function, $\mathrm{Y}$, which governs whether erosion is perceived $(\mathrm{Y}=1)$ or not $(\mathrm{Y}=0)$. The probability that observation $\mathrm{Yi}$ takes on the value 1 can be represented as a function of a vector of explanatory variables, $\mathrm{Xi}$, representing the physical setting, the farm household and the institutional environment. In general, the probability of perception of a given condition can be represented as:

$$
\mathrm{Pi}=\operatorname{Prob}(\mathrm{Yi}=1)=\mathrm{F}(\mathrm{Xi}, \mathrm{B})+\mathrm{ei}, \text { for } \mathrm{i}=1,2, \ldots, \mathrm{n}
$$

Where $\mathrm{Xi}$ is a vector of explanatory variables, $\mathrm{B}$ is a vector of unknown parameters (to be estimated), andeis a random error term. Assuming the model's random disturbance term, ei, follows the normal probability distribution $(0, \mathrm{~s} 2)$, the probability of perception can be defined in terms of an index which is converted into a probability value through the cumulative normal distribution function. The probit model takes the form $\mathrm{P}[\mathrm{Y}=1]=\mathrm{F}\left(\mathrm{b}^{\prime} \mathrm{X}\right)$, where $\mathrm{P}$ is probability of perception and $\mathrm{F}($.$) is the normal cumulative probability distribution function. The statistical$ relationship $\mathrm{P}(\mathrm{Y})=\mathrm{F}\left(\mathrm{b}^{\prime} \mathrm{X}\right)$ is estimated using maximum likelihood estimation. The marginal effect of an additional unit of some $\mathrm{X}$ variable can be computed using the estimated parameter coefficients.

In order to analyze how farmers perceive the productivity effect of land degradation, farmers were asked to estimate the perceived proportion of yield reduction due to land degradation ( $1=$ no reduction, $2=20 \%$ reduction, $3=25 \%$ reduction, $4=33 \%$ reduction, and $5=50 \%$ reduction) on each of their farmlands during a normal cropping year before any conservation measures had been taken on. These responses were represented both as continuous and ordinal values in separate models. The continuous values are the perceived rates of yield reduction. Ordered probit was used for the ordinal variable, and ordinary linear regression (OLS) was used for the continuous variable. In order to investigate the determinants of farmer perceptions of the impact of land degradation on agricultural productivity, the two models were estimated using the same explanatory variables:

\subsubsection{Variables Identified}

From previous empirical researches, literature reviews and the researcher personal experience explanatory variables of the study identified. Accordingly, explanatory variables included: biophysical/ village level biophysical factors (rainfall, topography and level of land degradation) and field level biophysical level factors (soil type, slope, shape of slope, and location of plot) that may aggravate soil erosion; socio-economic factors(number of livestock owned), household demographic characteristics(education, age and gender.)and socioinstitutional factors, ( contact with the agricultural extension service (affecting access to information), availability of soil and water conservation (SWC) project in the village, prior public conservation campaign works on the farmer's own land (for demonstration effects), and the current tenure status of the field). The physical factors that aggravate soil erosion, such as higher rainfall intensity, steep slopes and erodible soils, are hypothesized to raise farmer perceptions of soil erosion by aggravating soil loss. Distance of plot from homestead is expected to reduce perception, as distant plots are less frequently observed by farmers. The period of time the plot has been operated 
by the current owner is expected to raise erosion perceptions for the opposite reason. Field area (size) should raise perception since the absolute amount of soil and crop yield losses may be higher from larger plots. Farmers who have contact with extension services are expected to have higher erosion perception, since extension is expected to serve as a source of technical information to farmers. The availability of a resource conservation FFW project in the village is expected to raise erosion perception through its demonstration effect on the need for conservation measures. The effect of public campaign conservation work on the farmer's own plot is ambiguous; it may raise erosion perception through its demonstration effect or reduce perception through its effect on soil los (Table 1).

Table 1. Definition and units of measurement of explanatory variables used included in the model

\begin{tabular}{lll}
\hline Explanatory variables of the study & Variable type & Unit of measurement \\
\hline Age of the household head & Continuous & Measured in years \\
Gender of the household head & Dummy & 1 if the household head is male otherwise 0 \\
Education level of the household head & Continuous & Measured in years \\
Frequency of extension contacts per annum & Continuous & Measured in number of contact per year \\
Family size (adult equivalent) & Continuous & Measured in number \\
Participation in public SWC (days) & Continuous & Measured in number of days participated \\
Livestock size owned by the household (tropical livestock & Continuous & Measured in number \\
unit) & & \\
Landholding size & Continuous & Measured in hectares \\
Land ownership/tenure system & Dummy & One if owned 0 otherwise \\
Plot distance to residence & Continuous & Measured in minutes \\
Position of plot in watershed, upper part & Dummy & 1 if the plot found at upstream, 0 otherwise \\
Position of the plot in watershed, middle part & Dummy & 1 if the plot found at middle part 0 otherwise \\
Position of the plot in watershed, lower part & Dummy & 1 if the plot found at lower part 0 otherwise \\
Neighboring plots have SWC measures & Dummy & 1 if neighbor plot has SWC measures, 0 \\
& & otherwise \\
Plot received public SWC improvements & Dummy & 1 if the plot received public SWC interventions, \\
Age of plot (number of years since plot was cultivated by & Continuous & 0 otherwise \\
current owner) & Measured in years \\
\hline
\end{tabular}

\section{Results and Discussion}

\subsection{Socio-Economic and Demographic Attributes of Respondents}

The average land holding size in the study kebeles was about 1.2 ha. There was no report of landless farmers in any of the three villages. But there was a significant variation in the size of land holdings among households in the study area. Of the sampled households, the majority (48.33\%) possessed between $0.5-1.0$ ha land. Only $9.4 \%$ had more than two ha and some $33.33 \%$ had less than 0.5 ha (Table 2). Out of the total sample respondents 29.2 , $30.97,22.57$ and $17.26 \%$ respondents reported that the status of their farm plots slope steep, gentle steep and hills, moderate and flat/plain respectively.

Table 2. Demographic and Socio-economic attributes of the Respondents $(\mathrm{n}=120)$

\begin{tabular}{llll}
\hline Characteristics & & Frequency & Percentage \\
\hline Sex & Male & 87 & 72.5 \\
& Female & 33 & 27.5 \\
Age & $20-30$ & 17 & 14.17 \\
& $31-41$ & 21 & 17.7 \\
& $42-52$ & 47 & 39.17 \\
& $53-63$ & 27 & 22.5 \\
Education & $>63$ & 8 & 6.46 \\
& No formal & 27 & 22.5 \\
& Primary & 52 & 43.3 \\
& Secondary & 27.5 \\
& Certificate and above & 8 & 6.67
\end{tabular}




\begin{tabular}{llll} 
Farming experience (Years): & $1-10$ & 18 & 15 \\
& $11-21$ & 35 & 29.16 \\
Landholding size(ha) & $22-32$ & 42 & 35 \\
& $>32$ & 25 & 20.83 \\
Livestock ownership (TLU) & $<0.5$ & 40 & 43.33 \\
& $0.5-1$ & 58 & 18.33 \\
Family Size & $>1$ & 22 & 30.83 \\
& $0-2$ & 37 & 46.67 \\
Extension Service & $3-5$ & 56 & 22.5 \\
& $>5$ & 27 & 31.67 \\
Credit service & $2-4$ & 38 & 50 \\
& $5-7$ & 60 & 18.33 \\
Slope of the plots & $>7$ & 22 & 65 \\
& Access & 78 & 35 \\
& No access & 42 & 13.33 \\
& Access & 16 & 86.67 \\
& No access & 104 & 29.2 \\
& Steep & 66 & 30.97 \\
& Gentle Steep & 70 & 22.57 \\
& Moderate/gentle & 51 & 17.26 \\
\hline
\end{tabular}

The average family size per household in the study kebeles was reported to be 6 (table2) persons per household. The respondents from all the three kebeles that labour is available throughout the year but varies from season to season. Family labour is the main source of farm labour except for potato production for which farmers commonly use hired labour. Labour is highly demanded during planting and harvesting seasons in the study area. Due to shortage of agricultural land in the area, some farmers may also leave their village looking for employment in other places during the months of September to December.

Livestock are an integral part of the farming system in the district as well as in the study villages. That is, 83 percent of the sampled households owned livestock while 17 percent did not own livestock. The main purpose of keeping livestock is for draught power. Livestock products such as milk and meat have secondary importance to the farmers. Small ruminants are mainly used as income sources as well as for household consumption. The livestock production system commonly found in the villages is an extensive system where open grazing is the main style of feeding.

The district is characterized as a mixed crop livestock production system. Land preparation is mainly done by oxdrawn plough. The area has a bi-modal rainfall pattern with two distinct rainy and cropping seasons. The main rainy season (meher), which is also the main cropping season, extends from June to September. The short rainy season, known as "belg rain", usually covers the period from February to April. The respondents indicated that the small rainy season has become less dependable for cropping during recent years. As a result, better off farmers depend on irrigation for their farming operations during this period. The main crops grown in the study areas include wheat (Triticum aestivum), tef (Eragrostis tef), broad bean (Vicia faba), barley (Hordeum vulgare) and potato (Solanum tuberosum). Most of the available crop land is allocated for production of wheat, which indicates that it is the most preferred crop in the area. Crop residues are used as major sources of livestock feed during the dry season. However, small amounts of crop residues are sold as an income source and are also used for house construction, particularly for plastering of walls and thatching of roofs. Some farmers also use crop residues for mulching purposes to enhance fertility of the soil. Despite the importance of fodder crops as livestock feed, farmers in the area hardly grow improved forage crops. Moreover, the extension service to support forage development in the area appears to be weak and non-functional.

Credit sources for purchase of livestock and crop production are not satisfactory. Although credit facilities are available from microfinance institutions such as Oromia Saving and Credit Share Company and Busa Gonofa microfinance, most farmers do not use the services because of fear of risks associated with crop and livestock performance failures that could lead to failure of repayment of the loan. As survey result shows (table2) only $13.3 \%$ of the respondents used microfinance service (Table 2). Moreover, the credit services provided by the microfinance institutions are group based; which makes individual farmers accountable for the group members who are 
unable to pay their loan. It was also indicated that the service provision is limited to only once per year so that it may not be available when it is needed most.

The district is characterized as a mixed crop livestock production system. Land preparation is mainly done by oxdrawn plough. The area has a bi-modal rainfall pattern with two distinct rainy and cropping seasons. The main rainy season (meher), which is also the main cropping season, extends from June to September. The short rainy season, known as "belg rain", usually covers the period from February to April. The respondents indicated that the small rainy season has become less dependable for cropping during recent years. As a result, better off farmers depend on irrigation for their farming operations during this period. The main crops grown in the study areas include wheat (Triticum aestivum), tef (Eragrostis tef), broad bean (Vicia faba), barley (Hordeum vulgare) and potato (Solanum tuberosum). As the survey data reveals about $72.5 \%$ of the respondents produce potatato while 69.17,65, 55.83 and 51.83\% produces wheat, barley, teff and bean respectively (table 3 ). Most of the available crop land is allocated for production of wheat, which indicates that it is the most preferred crop in the area. Crop residues are used as major sources of livestock feed during the dry season. However, small amounts of crop residues are sold as an income source and are also used for house construction, particularly for plastering of walls and thatching of roofs. Some farmers also use crop residues for mulching purposes to enhance fertility of the soil. Despite the importance of fodder crops as livestock feed, farmers in the area hardly grow improved forage crops. Moreover, the extension service to support forage development in the area appears to be weak and non-functional

Table 3. The main crops grown in the study areas

\begin{tabular}{lll}
\hline Crops farmers produce in the study area & Frequency & Percentage \\
\hline Wheat & 83 & 69.17 \\
Barley & 78 & 65 \\
Teff & 67 & 55.83 \\
Bean & 62 & 51.67 \\
Potato & 87 & 72.5 \\
\hline
\end{tabular}

* Note: A multiple response frame was used. Hence, total count is more than the number of respondents

\subsection{Farmers' Perception on Land Degradation Hazard}

Response to the inquiry on whether the study area households perceived land degradation as a problem in their farm lands have shown (table 4 ) that $72 \%$ of the surveyed respondents perceived land degradation as being a serious problem in their farming and grazing plots. As indicated (table 4), the major cause of land degradation mentioned by $98 \%$ farmers was lack of conservation structures. The farmers' perceived various causes of land degradation in their farmland and surrounding landscapes. Overwhelming majority of farmers' in the study areas were aware that land degradation in various forms and levels was happening on their farm lands as well as in the surrounding landscapes. Table 4 presents the locally perceived land degradation causes that were mentioned by the respondents as being the contribution of the farming practices to the observed land/soil degradation in the study areas. About $35 \%$ of the respondents associated land degradation to low adoption and sustained implementation of soil and water conservation measures used in their farmlands while $32.5 \%, 30.83 \%, 28.33 \%, 27.5 \%, 25.83 \%$ and $18.33 \%$ considered Cultivation of marginal areas and steep slopes; overgrazing and continuous cropping; torrential rains (high intensity rainfalls); expansion of eucalyptus trees; deforestation and clearing of vegetation and soil erosion vulnerable soil type reported to be responsible for the land degradation and soil erosion proms respectively. This finding clearly corroborates with Tesfa, and Mekuriaw, (2014) report which elucidates those vast areas of the highlands of Ethiopia could be classified as suffering from severe to moderate soil degradation. Increasing intensification and continuous cultivation on sloping lands without supplementary use of soil amendments and conservation practices poses a serious threat to sustainable land use. In addition, Seid (2009) stated that the apparent increase of soil erosion over the past generation is not the result of a decline in the skills of farmers but rather the result of the pressures on farmers to produce more. Hence, farmers of the study area were aware of soil erosion but they are forced to intensify and produce more food crops for their basic livelihood.

However, as the FGD participants elucidated the major factor catalyzing soil erosion on the steep slopes was that farmers are increasingly destroying contour bunds on terraces to pave way for more farmland. As a result, soil erosion has been accelerated which in periods of heavy rainfalls results in silting and flooding of the valley-bottom 
fields and landslides are also becoming very common. This regular practice has reduced the attraction of placing more long-term erosion control devices such as grass lines or hedgerows of agro-forestry species. Also FGD participants explained that land has been cultivated frequently to produce food crop for rapidly growing population. Particularly, owning small size and increasing demands for food crop production forced farmers to cease longstayed traditional ways of soil fertility management such as fallowing, manuring, terracing, and leaving crop residues on the fields. Fallowing was nearly absent due to land shortage and manuring was rare as it is used as source of energy. Crop residues were used for other purposes like forage, construction, and otherwise some farmers burn immediately after harvest.

Table 4. Farmers' Perception on Land Degradation and soil erosion in the study area

\begin{tabular}{lccc}
\hline $\begin{array}{l}\text { Farmers' perceived causes land } \\
\text { degradation }\end{array}$ & Frequency $(\mathbf{n = 1 2 0})$ & Percentages \\
\hline $\begin{array}{l}\text { Overgrazing and continuous } \\
\text { cropping }\end{array}$ & 37 & 25.83 & 30.83 \\
$\begin{array}{l}\text { Deforestation clearing of } \\
\text { Vegetation }\end{array}$ & 31 & & 32.5 \\
$\begin{array}{l}\text { Cultivation of marginal and steep } \\
\text { slope areas }\end{array}$ & 39 & 35 & \\
$\begin{array}{l}\text { Low adoption of conservation } \\
\text { measures and practices }\end{array}$ & 42 & & 28.33 \\
$\begin{array}{l}\text { Torrential rains/high intensity of } \\
\text { rainfall (extreme weather events) }\end{array}$ & 34 & 18.33 & \\
Erosion vulnerable soil type & 22 & & 27.5 \\
Expansion of Eucalyptus Trees & 33 & & \\
\hline
\end{tabular}

* Note: A multiple response frame was used. Hence, total count is more than the number of respondents

\subsection{Farmers' Perceived Indicators of Land Degradation}

Farmers were asked to respond how they distinguish when land degradation occurs on their farmlands in openended questions. Some of the responses were elucidated: when there is overflow of constructed ditches and damage their crops; when there is siltation in and out of their field mostly at the lower field border; when rills appeared on their fields, when the color of soil in the upper part of the field goes to red whereas the lower part goes to black. So the result from this study reveals that there are numerous long-established traditions communities use to estimate and to elucidate the condition of the land and the soils they are cultivating. Generally, a healthy and vigorous crop growth, reflected by a good crop stand in the field, was used as an important indicator that the soil is fertile enough, if moisture and other factors are not limiting. Under such circumstances, even if the weather conditions worsen during the growing season such that final yields are poor, the farmer would have realized the potential fertility of a certain piece of land. A stunted crop with less vigorous growth in the field when other factors such as moisture are considered not limiting was locally perceived to indicate a high probability that soils on which the crop is growing are of low quality and infertile. Majority of respondents (57.5\%) considered crop yields as the best measure to comprehend land/soil status. Although it was noted that declining crop productivity could be a clear indicator of declining soil fertility, and hence soil degradation and land degradation. As survey result reveals (table 5), about $30.83,30,28.33,27.5$ and $24.16 \%$ of the respondents perceived stunted crop, grasses, vegetation and tree growth, decline in soil fertility/ loss of top soil, Absence of grasses and vegetation cover, Gullies and rills formation/development and Presence of exposed roots were the indicators of land quality perceived by farmers respectively.

Table 5. Farmers' Perceived Indicators of Land Degradation

\begin{tabular}{lcc}
\hline Farmers' Perceived Indicators & Frequency $(\mathbf{n}=\mathbf{1 2 0})$ & Percentages \\
\hline $\begin{array}{l}\text { Declining crop yield and } \\
\text { productivity }\end{array}$ & 69 & 57.5 \\
Gullies and rills & 33 & 27.5 \\
\hline
\end{tabular}




\begin{tabular}{lcc}
\hline $\begin{array}{l}\text { formation/development } \\
\text { Change in the colour of the soil }\end{array}$ & 24 & 20 \\
$\begin{array}{l}\text { Sedimentation of soil and sandy } \\
\text { materials }\end{array}$ & 26 & 21.67 \\
$\begin{array}{l}\text { Decline in soil fertility/ loss of top } \\
\text { soil }\end{array}$ & 36 & 30 \\
$\begin{array}{l}\text { Absence of grasses and vegetation } \\
\text { cover }\end{array}$ & 34 & 28.33 \\
$\begin{array}{l}\text { Presence of exposed roots } \\
\begin{array}{l}\text { Stunted crop, grasses, vegetation } \\
\text { and tree growth }\end{array}\end{array}$ & 29 & 24.16 \\
\hline
\end{tabular}

* Note: A multiple response frame was used. Hence, total count is more than the number of respondents

The majority of the farmers reported that the occurrence of gully and rill erosions were the principal land degradation indicating feature (27.5\%) on their farmlands (Table 5). But not all the respondents perceived sheet erosion as a problem, which has been estimated in the literature to contribution to soil up to $30 \%$ of actual soil loss (Tesfaye et al 2014; Assefa and Hans-Rudolf, 2016). Farmers have awareness of identifying soil fertility and land quality and classify soils based on their fertility, consistence, color and moisture. $21.67 \%$ of the farmers (table 4) explained the occurrence of land degradation/soil erosion in the study area in general and their farms by the presence of accumulated soil at the bottom of conservation structures and lower positions. When the runoff lacks the capacity to transport the uploaded soil, it tends to unload it at the middle or end of the channel as sediment. If the deposit is black in color, farmers consider it as removal of fertile soil from some elsewhere in the watershed. In addition to these, farmers also mentioned slope steepness and root exposure (observation of roots of trees on the surface) as indicators of existence of soil erosion on their lands. $20 \%$ of respondents elucidate land quality status can be recognized by color change of their plots soil from dark black to redish color when losing the top fertile soil. These results conform with those of Bewket and Sterk (2003); who reported that elucidates the existence of severe soil erosion problem by observing the stoniness of soil and color of soil changing from dark/black to red one.

The consciousness of these indicators could confirm that rural communities are aware of their environment and its related problems, and particularly so with those which affect the farm productivity and/or those that resulted into more visible landscape changes such as soil erosion. However, some of the respondents argued that soils are naturally infertile suggests that productivity has declined significantly within living memory and that people were unaware that their yields were probably rather low from the outset.

\subsection{Farmers'Perception on Severity of Land Degradation and Its consequences on land productivity}

From the total respondents their perception on the extent of land degradation problem were assessed and about $47.5 \%$ of the sampled households perceived it as severe, while $33.3 \%$ as moderate; $11.67 \%$ as minor problem. Only about $7.5 \%$ of farmers indicated that there is no land degradation problem on their plots of lands (table 6). The farm households were also asked their perception about the consequences of land degradation $68 \%, 22 \%$, and $10 \%$ mentioned yield decline, reduced farm plot and both respectively. This might lead the farmers towards the perception of underlying and proximate causes of soil fertility decline and at the end to the adoption decision on various options of fertility enhancing technologies of physical soil and water conservation practices. This perception may be influenced by differences in socio-economic characteristics inherent among the local people.

Table 6. Farmers' perception on the level of severity of land degradation hazards

\begin{tabular}{llll}
\hline Land Degradation Hazard Level of Severity & $\begin{array}{l}\text { Frequency } \\
\text { Response }\end{array}$ & of Percentage \\
\hline Severe & 57 & 47.5
\end{tabular}




\begin{tabular}{lll} 
Moderate & 40 & 33.3 \\
Slight/minor & 14 & 11.67 \\
No land degradation problem & 9 & 7.5 \\
\hline
\end{tabular}

* Note: A multiple response frame was used. Hence, total count is more than the number of respondents

\subsection{Determinants of Farmer Perceptions on impacts of land degradation on agricultural productivity reduction}

Table 7. Regression results for farmer perceptions of productivity decline impact of land degradation

\begin{tabular}{|c|c|c|}
\hline Variable & $\begin{array}{l}\text { Impact of land degradation on } \\
\text { agricultural productivity (std.err) } \\
\text { (Ordered probit) }\end{array}$ & $\begin{array}{llr}\text { Impact of land degradation on } \\
\text { agricultural } & \text { productivity } & \text { (robust } \\
\text { std.err)" } & \text { (Ordinary } & \text { linear } \\
\text { regression ) } & & \\
\end{array}$ \\
\hline Sandy soil (If plot has sandy soil, $(.0,1)$ ) & $0.180(0.136)$ & $-0.024(.030)$ \\
\hline Silt soil (If plot has silt soil, $(.0,1)$ ) & $-0.168(0.224)$ & $0.027(0.26)$ \\
\hline Loam soil (If plot has loam soil, $(.0,1)$ ) & $-0.175(.122)$ & $-0.022(.017)$ \\
\hline Degree of slope (Degree of plot slope) & $0.031(.010)^{* * *}$ & $0.004(.001)^{* *}$ \\
\hline $\begin{array}{l}\text { Convex slope (If shape of plot slope is } \\
\text { convex, }(.0,1))\end{array}$ & $0.363(0.231)$ & $0.062(0.029)^{* *}$ \\
\hline $\begin{array}{l}\text { Concave slope (If shape of plot is } \\
\text { Concave, }(.0,1))\end{array}$ & $0.417(0.196)^{* *}$ & $0.057(0.032)$ \\
\hline Mixed slope (If shape of plot is mixed, $(.0,1)$ ) & $0.173(0.186)$ & $0.26(0.028)$ \\
\hline Distance from residence & $-0.346(0.133)^{* *}$ & $-0.053(0.019)^{* * *}$ \\
\hline Land holding size(ha) & $-0.12(.003)^{* * *}$ & $-0.001(.002)^{* * *}$ \\
\hline $\begin{array}{l}\text { Location at upper slope (If plot is located at } \\
\text { upper slope of watershed,(.0,1)) }\end{array}$ & $-0.13(.002)^{* * *}$ & $-0.001(.001)^{* * *}$ \\
\hline $\begin{array}{l}\text { Location at lower slope (If plot is located at } \\
\text { middle slope of plot, }(.0,1) \text { ) }\end{array}$ & $0.026(0.276)$ & $0.008(0.016)$ \\
\hline $\begin{array}{l}\text { Location at lower slope (If plot is located at } \\
\text { lower slope of watershed,(.0,1)) }\end{array}$ & $0.286(0.153)$ & $0.037(0.017)$ \\
\hline $\begin{array}{l}\text { Hilly village If village is predominantly } \\
\text { hilly, }(.0,1))\end{array}$ & $0.228(0.268)$ & $0.037(.026)$ \\
\hline $\begin{array}{l}\text { Dung as fuel (If dung is used primarily as fuel } \\
\text { wood in village, }(0,1) \text { ) }\end{array}$ & $-0.418(.151)^{* *}$ & $0.034(.024)$ \\
\hline $\begin{array}{l}\text { Distance to fetch fuel wood (round trip (in } \\
\text { walking hours)) }\end{array}$ & $-.066(.206)$ & $-.009(.013)$ \\
\hline Age of household head (years) & $-0.12(.003)^{* * *}$ & $-0.001(.002)^{* * *}$ \\
\hline Male head of household $(0,1)$ & $0.279(0.142)^{* * *}$ & $0.020(0.023)$ \\
\hline Literate head of household $(0,1)$ & $0.269(0.136)^{* * *}$ & $-0.010(.029)$ \\
\hline $\begin{array}{l}\text { Age of plot (number of years since plot was } \\
\text { cultivated by current owner) }\end{array}$ & -0.006() .011 & $-0.011(.002)$ \\
\hline $\begin{array}{l}\text { Owner operator (If plot is owned by current } \\
\text { operator)) }\end{array}$ & $0.149(.012)$ & $0.021(.022)$ \\
\hline $\begin{array}{l}\text { SLM available (If SLM project is available in } \\
\text { village, }(.0,1) \text { ) }\end{array}$ & $0.286(.151)^{* *}$ & $0.037(.022)^{* * *}$ \\
\hline $\begin{array}{l}\text { Extension contact (If household had extension } \\
\text { contact, }(.0,1))\end{array}$ & $-.344(.111)^{* * *}$ & $-.050(.016)^{* * *}$ \\
\hline Constant & ------- & $0.293(.040)$ \\
\hline Chi-square/F & 88.44 & 6.52 \\
\hline Prob >chi-square/ F & 0.0000 & 0.0000 \\
\hline Pseudo R-square/ R-square & 0.0458 & 0.2685 \\
\hline $\mathrm{N}$ & 120 & 120 \\
\hline
\end{tabular}

$* *, * * *$ Significant at $5 \%$ and $1 \%$, respectively. 
Frequency of Extension contact: As hypothesized, extension contact is found to have a significant positive influence on the perception of the severity and productivity impact on agricultural productivity. Farmers with more frequent contact with extension agents were more likely to perceive impact of land degradation on agricultural productivity decline in their plots as compared with those who had lesser extension contact frequency. This may be explained by the fact that scientific information and research result reports that farmer gain from extension agents help them to aware and understand the severity and effects of land degradation on agricultural productivity. Therefore, Farmers who had frequent contact with extension agents perceived productivity decline associated with land degradation. Farmers with more frequent contact with extension agents were more likely to perceive severe land degradation in their plots as compared with those who had less extension. The number of contacts that farmers had with agricultural extension agents was found to positively and significantly $(\mathrm{p}<0.01)$ affect farmers perception of land degradation impact (Table 7).

Availablity of SLM project in the village: implementation of SLM project in the village positively influences and aware farmers about the risk of decline in agricultural land productivity due to land degradation and soil erosion. This could justified by SLM projects effort of attempt to participate the farmers in processes and awareness creation and capacity building through experience sharing from other successful project areas. Participation/training on agricultural land management SWC measures and etc. has a positive and significant effect on conservation perceptions. Farmers who participated in training by development agents on SWC works were more aware of soil erosion and conservation than those who did not participated. In their finding, Assefa, and Hans-Rudolf (2016).) in Ethiopia reported that training of farmers and their participation in extension workshops improves their perception of soil degradation problem and facilitates the adoption of improved technologies. This is precisely because those farmers who have plots within the catchment have the possibility to meet the project staff and be well informed about the consequences of soil erosion than those who own land outside the catchment. An anticipated, farmers' perception of soil erosion problem (PERCEPTN) affects the adoption of soil conservation measures positively and significantly. The implication is that farmers who feel that their farmlands are prone to soil erosion are more likely to adopt physical soil conservation measures than those who do not perceive the problem of soil erosion

Age of household head: The output from the model reveals that age of the household head has a negative influence on the perception of the risk of decline in agricultural land productivity due to land degradation and soil erosion. This could be because of aged farmers tended to perceive severe yield loss or productivity decline, in contradiction to other finding that younger farmers perceived higher erosion.

Educational level of household heads: Education of the head of the household significantly and positively determined farmers' perception of the risk of decline in agricultural land productivity due to land degradation and soil erosion. Older household heads were less likely to perceive erosion. Those younger farmers were more prone to perceive erosion may be due to greater education, higher access to information and a longer planning horizon, or simply the fact that older farmers might have grown accustomed to soil erosion, considering it a normal process. Farmers with higher level of formal educational attainment were most likely to perceive land degradation risk in their plots as compared with less educated farmers with other factors held constant. Farmers with more education were more likely to perceive severe land degradation in their plots as compared. With less educated farmers (coef. $=0.136, \mathrm{p}<0.01)$, with other factors held constant (Table 7). Possible explanation is that educated farmers tend to be better access to research output reports and generally to update information about the risks associated with land degradation and soil erosion and hence tend to spend more time and money on soil conservation. This is because literate farmers often serve as contact farmers for extension agents in disseminating information about agricultural technologies from government agencies. The odds ratio also suggests that if a farmer is educated, other factors held constant, the likelihood of awareness will be two times higher than an illiterate farmers. My findings reveals that the level of education attained by household heads was more likely to facilitate farmers in perceiving the risk of land degradation impact on agricultural productivity in their plots, which is in agreement with the findings of previous studies (Ervin \& Ervin, 1982; Asrat et al., 2004)

Slope of the plot: Farmers also perceived greater yield loss on steeper plots and on plots with slope shapes that aggravate soil loss. These factors were associated with higher erosion perception. Slope was found to have a positive significant effect $(\mathrm{p}<0.1)$, implying that farmers with plots in steeply sloped areas are more likely to perceive the impact of plot gradient on severity of soil erosion. This finding is in agreement with that of Teshome et al. (2016), who found a positive relationship between slope and soil erosion severity. The shape of the plot in terms of slope was also significant. The perception of yield impact of erosion was not influenced by soil type or location of plot. More distant plots were associated with lower yield reduction, consistent with the result that such 
plots were also associated with less likelihood of perceived soil loss. The model output reveals that the upstream areas were more likely to be perceived to be affected by soil erosion, whereas the downstream farmlands were less likely to be perceived in that manner. These results conform to those of Bewket \& Sterk (2003) and Tefera \& Sterk (2010), who reported that the perceived severity of soil erosion was site specific, that is, relatively higher in upstream areas and lower in downstream fields.

Distance from residence: Distant plots were perceived to be more prone to soil erosion, probably because the farther the plot is from the farmer's residence, the less attention it receives and the likelihood of severe soil erosion increases. This explanation is consistent with the results of Teshome et al. (2016) and Tefera \& Sterk (2010), who found that more distant plots received less care as compared to nearby plots. Moreover, Teshome et al., 2016). reported that plots receiving less care were very likely to become eroded because of soil nutrient depletion, particularly organic matter content, and increased soil loss through water erosion.

Farmholding size: farm holding size was also important factors. The larger the farm holding size, the higher is the likelihood of witnessing rills, surface runoff, sediment deposition and redeposit ion by farmers (Bewket \& Sterk, 2003). Larger parcel size may create a positive incentive for small-scale farmers to invest in SWC technologies (Tesfaye et al., 2014; Teshome et al., 2016). This is presumably true in subsistence agriculture because farmers assume that SWC technologies compete for space on small plots, which reduces productivity in the short run, thereby increasing farmer reluctance to apply countermeasures (Tesfaye et al., 2014).

\subsection{Conclusion and Policy Implication}

Farmers in the study area were generally aware of and perceived soil erosion as a serious problem and its effect on agricultural land productivity. The possibility of perceiving its impact on agricultural land productivity from slight to severe was primarily determined by institutional and demographic factors as well as weakly by biophysical factors. The socio-institutional and demographic determinants of the effects of land degradation and soil erosion risks on agricultural productivity decline point to policy implications for public inclusive SLM practices and capacity building programs as well as bringing back and indigenous land management practices to research and learning platforms for sustainable and desirable societal betterment. The finding of this study is the need to increase farmers' perception of soil erosion problem through the provision of knowledge and demonstration of gains and risk reduction characteristics of soil conservation practices. This important because the extent to which farmers understand and feel the need for controlling soil erosion affects adoption of soil conservation measures positively. Therefore, it is important to design soil conservation practices, which couple modern scientific knowledge with indigenous technical knowledge to facilitate their dissemination and ensure their sustainability.

\section{Acknowledgement}

This study was undertaken with a financial support from Ambo University, is sincerely acknowledged. The author also would like to thank the anonymous referees for their useful and pertinent comments on an earlier version of this paper. Many thanks are extended to the farmers in Jeldu District who are enthusiastically participated in this study and for their inspirations and willingness for the interview that paved a way towards completion of this work. The development workers of the Jeldu district are also sincerely thanked for their efforts to support the researcher by conducting the survey.

\section{References}

Achamyeleh, K. (2015). Integration of Acacia decurrens (J.C. Wendl.) Willd. into the farming system, its effects on soil fertility and comparative economic advantages in Northwestern Ethiopia. MSc Thesis, Bahir Dar University: Bahir Dar, Ethiopia; 140.

Aklilu, A. (2006). Caring for the Land Best Practices in Soil and Water Conservation in Beressa Watershed, Highlands of Ethiopia. Tropical Resource Management Papers, No. 76.

Alemayehu, M., Amede, T., Böhme, M., \& Peters, K. (2013). Collective management on communal grazing lands: its impact on vegetation attributes and soil erosion in the upper Blue Nile basin, northwestern Ethiopia. Livestock Science, 157, 271-279. https://doi.org/10.1016/j.livsci.2013.06.024

Amsalu, A., \& de Graaff, J. (2007). Determinants of adoption and continued use of stone terraces for soil and water conservation in an Ethiopian highland watershed. Ecological Economics, 6, 294-302

Asrat, P., Belay, K., \& Hamito, D. (2004). Determinants of farmers' willingness to pay for soil conservation practices in the southeastern highlands of Ethiopia. Land Degradation \& Development, 15, 423-438. https://doi.org/10.1002/ldr.623.

Assefa, D. (2009). Assessment of Upland Erosion Processes and Farmer's Perception of Land Conservation in 
Debre-Mewi Watershed, Near Lake Tana, Ethiopia. A Thesis Presented to the Faculty of Graduate School of Cornell University in Partial Fulfillment of the Requirements for the Degree of Masters of Professional Studies.104p.

Assefa, E., \& Hans-Rudolf, B. (2016). Farmers' perception of land degradation and traditional knowledge in southern Ethiopia-Resilience and stability. Land Degradation and Development, 27(6), 1552-1561. https://doi.org/10.1002/ldr.2364

Bekele, W., \& Drake, L. (2003). Soil and water conservation decision behavior of subsistence farmers in the Eastern Highlands of Ethiopia: a case study of the Hunde-Lafto area. Ecological Economics, 46, 437-451.

Bewket, W., \& Sterk, G. (2002). Farmers' participation in soil and water conservation activities in the Chemoga watershed, Blue Nile basin, Ethiopia. Land Degradation \& Development, 13, 189-200. https://doi.org/10.1002/ldr.492

Bewket, W., \& Sterk, G. (2003). Assessment of soil erosion in cultivated fields using a survey methodology for rills in the Chemoga watershed, Ethiopia. Agriculture, Ecosystems \& Environment 97: 81-93. https://doi.org/10.1016/S0167-8809(03)00127-0.

Bewket, W., \& Teferi, E. (2009). Assessment of soil erosion hazard and prioritization for treatment at the watershed level: case study in the Chemoga watershed, Blue Nile Basin, Ethiopia. Land Degradation \& Development 20, 609-622. https://doi.org/10.1002/ldr.944.

Bezuayehu, T., \& Geert, S. (2010). Land management, erosion problems and soil and water conservation in Fincha'a watershed, western Ethiopia

Ervin, C. A., \& Ervin, D. E. (1982). Factors Affecting the use of Soil Conservation Practices: Hypothesis, Evidences, and Policy Implications. Land Economics, 38(3), 277-292.

FAO (2011). Sustainable Land Management in Practice Guidelines and Best Practices for Sub-Saharan Africa. Rome, 2011.

FAO. (2006). Preparation of a Global Report on the State of Land and Water Resources, SoLAW. Land and Water Development Division, FAO, Rome, 2006. In-progress Draft Report - Version 01.

FAO. (2010). Investment Centre Database of Projects. Rome, Food and Agriculture Organization of the United Nations.

Haregeweyn, N., Tsunekawa, A., Nyssen, J., Poesen, J., Tsubo, M., Meshesha, D. T., Schütt, B., Adgo, E., \& Tegegne, F. (2015). Soil erosion and conservation in Ethiopia: a review. Progress in Physical Geography, 39 , 750-774. https://doi.org/10.1177/0309133315598725.

Million, T., \& Belay, K. (2007). Factors influencing adoption of soil conservation measures in southern Ethiopia: The Case of Gununo Area. Journal of Agriculture and Rural Development in the Tropics and Subtropics, 105(1), 49-62

Pender, J., \& Gebremedhin, B. (2004). Impacts of policies and technologies in dryland agriculture: evidence from northern Ethiopia. In: S.C. Rao (Ed.), Challenges and Strategies for Dryland Agriculture, American Society of Agronomy and Crop Science Society of America, CSSA Special Publication 32, Madison, WI.

Seid, H. (2009). Determinants of Physical Soil and Water Conservation Practices: The Case of Bati District, Oromyia Zone, Amhara Reion, Ethiopia. M.Sc. Thesis Presented to the School of Graduates of Alemaya University, Alemaya. 162p.

Tegene, B. (1992). Farmers' perceptions of erosion hazards and attitudes towards soil conservation in Gunono, Wolayita, southern Ethiopia. Ethiopian Journal of Development Research, 14, 31-58.

Tesfa, A., \& Mekuriaw, S. (2014). The Effect of Land Degradation on Farm Size Dynamics and Crop-Livestock Farming System in Ethiopia: A Review. Open Journal of Soil Science, 4, 1.

Tesfaye, A., Deneke, T. T., \& Selassie, Y. G. (2014a). Determinants of maintenance decision of introduced soil and water conservation practices in Fagita Lekoma District, North West Highlands of Ethiopia. Ethiopian Journal of Applied Sciences \& Technology, 5, 1-17.

Tesfaye, A., Negatu, W., Brouwer, R., \& Zaag, P. (2014b). Understanding soil conservation decision of farmers in the Gedeb watershed, Ethiopia. Land Degradation \& Development 25: 71-79. https://doi.org/10.1002/ldr.2187.

Teshome, A., de Graaff, J., Ritsema, C., \& Kassie, M. (2016). Farmers' perceptions about the influence of land 
quality, land fragmentation and tenure systems on sustainable land management in the north western Ethiopian highlands. Land Degradation \& Development 27: 884-898.https://doi.org/10.1002/ldr.2298

Woodfine, A. (2009). The Potential of Sustainable Land Management Practices for Climate Change Mitigation and Adaptation in Sub-

World Bank (WB). (2012). Managing land in a changing climate: an operational perspective for Sub- Saharan Africa. Draft version Report No.: 54134-AFR. WB, Washington D.C.

\section{Copyrights}

Copyright for this article is retained by the author(s), with first publication rights granted to the journal.

This is an open-access article distributed under the terms and conditions of the Creative Commons Attribution license (http://creativecommons.org/licenses/by/4.0/). 